KUGEL, James L. How to read the Bible: a guide to Scripture, then and now. New York: Free Press, 2007. $819 p$.

\title{
Como ler a Torah, segundo James L. Kugel
}

Julio Jeha*

Os estudos bíblicos modernos, iniciados no século 19, tiveram um marco fundamental que poderia ser considerado um divisor de águas com os ataques de 11 de Setembro. Se por um lado, os fundamentalistas viram no ataque à Nova York o cumprimento de profecias apocalípticas, o que renovou o interesse pelas Escrituras, por outro, acadêmicos e autoridades políticas reconheceram a necessidade de se estudar o islamismo, visto que os terroristas se diziam empenhados numa chamada "guerra santa" contra os não-muçulmanos. Nesse cenário de confronto de civilizações, para usar a expressão que Bernard Lewis cunhou em "The Roots of Muslim Rage", já em setembro de 1990, a atenção voltada para o Islã e seus aspectos positivos provocou uma onda de manifestações que intentavam demonstrar a superioridade da cultura ocidental, de base cristã. Ainda que não se possa apontar uma relação causal direta, tal contexto deu novo alento à pesquisa sobre a Bíblia, seja ela hebraica ou cristã, no início do século 21.

Dentre as obras de exegese recentes, destaca-se a de James L. Kugel, How to read the Bible: a guide to Scripture, then and now (Como ler a Bíblia: um guia para as Escrituras, naquele tempo e hoje em dia), de 2007. Escrita por um judeu religioso, ela se dirige a um público mais amplo do que outros religiosos ou apenas judeus. Ela se oferece como obra de consulta para todos os interessados no livro fundador do judaísmo e do cristianismo. Tem o propósito de divulgar parte dos modernos estudos bíblicos, que o público em geral desconhece, principalmente, o que tange à distância que separa as análises antigas das contemporâneas, assim como o papel crucial que os primeiros intérpretes tiveram na fixação da mensagem bíblica.

Ex-professor de Harvard, onde seus cursos sobre literatura hebraica atraíam centenas de alunos a cada semestre, James Kugel vive, hoje, em Israel, ensinando na Universidade Bar Ilan. Em 2006, publicou The ladder of Jacob, que havia sido precedido por The God of old (2003). No final do século passado lançou Great poems of the Bible(1999), Traditions of the Bible(1998), The Bible as it was (1997), In Potiphar's house(1990), Poetry and prophecy (1990), On being a Jew (1990) e The idea of Biblical poetry (1982). Está preparando The testaments of the twelve patriarchs e The outside books: ancient Jewish writings outside of the Biblical canon. Em meio a tantos trabalhos e publicações, ainda encontra tempo para dirigir o instituto de história da Bíblia Hebraica da universidade onde leciona.

A produção de Kugel se junta à de Karen Armstrong, a ex-freira que se tornou escritora de livros populares sobre as religiões. Em The Bible: a biography (2007), Armstrong descreve a gênese dos livros da Bíblia, além de examinar quase dois milênios de interpretação feita por bispos e rabinos, filósofos e místicos, crentes e ateus, mostrando que as múltiplas abordagens exegéticas desautorizam qualquer veleidade fundamentalista de uma única visão correta. Sua biografia da Bíblia é o último título de uma lista que inclui The great transformation: the beginning of our religious traditions (2007), A history of God: the 4,000-year quest of Judaism, Christianity, and Islam (2004), além de biografias de Maomé, Buda e São Francisco de Assis.

Kugel, no entanto, se interessa mais pela hermenêutica do que pela vida dos autores, o que o aproxima mais de Robert Alter, outro professor universitário que se ocupa da Bíblia e sua tradução e interpretação. Alter traduziu e comentou tanto o Pentateuco, em The five books of Moses (2005), como os Salmos, em The Book of Psalms (2007). Kugel, ao contrário, traduziu pouca coisa em How to read the Bible, preferindo usar duas traduções modernas, a da Jewish Publication Society e a New Revised 
Standard Version. Para ele, o trabalho de Alter é imaginativo (no bom sentido, segundo ele), mas os textos da JPS e da NRSV lhe parecem mais embasados pelos estudos contemporâneos.

Em How to read the Bible, Kugel tenta fundir duas maneiras irreconciliáveis de ler a Bíblia Hebraica: o método usado pelos antigos intérpretes e o usado pelos especialistas modernos. Ao ler uma passagem bíblica, os antigos partiam, segundo o estudioso, de quatro premissas: o sentido era quase sempre oculto; trazia uma mensagem para o contexto do leitor; não se contradizia e fora inspirada por Deus. Essa maneira de ler levou à dedução de ensinamentos e até mesmo de passagens nunca mencionados na Bíblia, muitas vezes "descobrindo" doutrinas ou idéias que só vieram a aparecer séculos depois de o texto ter sido escrito. A interpretação dos antigos foi sancionada nas igrejas e nas sinagogas, representada em diversas formas de arte, repetida vezes sem fim até ser vista como verdades bíblicas. Contra essa Bíblia interpretada surge a leitura moderna baseada em descobertas arqueológicas, estudos lingüísticos e métodos interpretativos que abalam, quando não contradizem frontalmente, as explicações dos antigos intérpretes.

Esse conflito coloca os leitores atuais num dilema, segundo Kugel. Por um lado, a maneira de ler dos antigos é crucial para aquilo que muitos ainda querem acreditar sobre a Bíblia e o que ela quer dizer. Por outro, se esses leitores acompanham os especialistas modernos, "toda a Bíblia cai por terra: muito de sua instrução ética, seus mandamentos básicos, visões proféticas e preces vindas do coração se mostrarão diferente do que pareciam ser". Um escândalo maior ameaça surgir: "na verdade, a inspiração divina das Escrituras estará solapada". Kugel, no entanto, é um pesquisador honesto e se recusa a fingir que desconhece os resultados dos estudos modernos. Surge daí a pergunta tremenda que o levou a escrever seu último livro: como ler a Bíblia?

O livro se divide em 36 capítulos, da criação do mundo (e Adão e Eva) até a história de Daniel, passando pelos episódios principais da formação do judaísmo como religião oficial dos israelitas e precursora do cristianismo. Vão por terra as crenças populares de que Eva ofereceu a maçã a Adão, que David escreveu os Salmos e que a menção de Isaías à gravidez de uma jovem mulher seja prova da imaculada concepção. Acompanhando vagamente a estrutura da Torá, a obra de Kugel demonstra sua vasta erudição e sua familiaridade com o que de melhor e mais contemporâneo se produz na área dos estudos bíblicos. O capítulo 13, "Moisés no Egito", por exemplo, traz um breve panorama da egiptologia e sua relação com o Êxodo. No capítulo 17, "Uma religião de leis", encontram-se os códigos locais contemporâneos, como os de Hamurabi (c. 1700 a.C.), Eshunna (c. 1930 a.C.) e LipitIshtar (c. 1870 a.C.). Um resumo claro e competente da hipótese documental - a teoria de que o Pentateuco resulta do agrupamento de textos de autoria diversa - se encontra no capítulo 19, "P e D".

Como os críticos desde meados do século 19 insistem, também para Kugel a Bíblia deve ser tomada ao pé da letra, pois foi escrita de acordo com as necessidades de um povo específico que vivia em época e local determinados. E mais, ela foi escrita, reunida e retrabalhada por mãos diferentes com propósitos diferentes. O desafio à tradição da autoria divina - e portanto da autoridade do livro - parece inevitável. Cada vez que Kugel indica um aparente "remendo" usado pelos autores bíblicos para harmonizar dois textos ostensivamente contraditórios, cada vez que ele cita outra fonte com linguagem muito semelhante - ou muito diferente - daquela encontrada na Bíblia, mais um elemento é acrescido ao argumento que o autor diz estar construindo no capítulo final do livro. Tal estratégia aumenta o interesse do leitor e cria expectativas de encontrar uma resposta à altura da pergunta crítica que motiva Kugel: é possível, aos fiéis, conciliarem sua Bíblia (isto é, a dos antigos intérpretes) com a dos estudiosos modernos?

Sem querer contar o fim da história, é possível dizer que o próprio Kugel propõe que "os estudos bíblicos modernos e o judaísmo tradicional são e devem sempre permanecer completamente irreconciliáveis". Tampouco as soluções para ler a Bíblia numa época crítica e não sem um retorno a certo fundamentalismo, racional até certo ponto, a partir de leituras cristãs, a maioria de tendência 
evangélica ou liberal, lhe parece apropriadas. No entanto, as razões que Kugel dá para a sua preferência pelos antigos intérpretes parecem insuficientes. Se os estudiosos contemporâneos estão certos, parece difícil acreditar na autoria divina da Bíblia. O que, então, torna as Escrituras uma obra especial? Se por "especial" entende-se mais verdadeira ou superior a toda outra literatura, a resposta é: nada. Kugel, entretanto, conclui que os intérpretes antigos fornecem a maneira de considerá-la desse modo. Assim, o leitor preocupado com a possibilidade de perder a fé por causa dos estudos bíblicos contemporâneos pode se tranqüilizar: Kugel deixa uma saída. Mas não é uma saída para os fracos em sua crença.

* Julio Jeha é professor associado de literaturas em inglês na UFMG, tradutor e coordenador do Núcleo de Estudos de Crimes, Pecados e Monstruosidades na UFMG. 